\title{
Mineral Element Composition in Grain of Awned and Awnletted Wheat (Triticum aestivum L.) Cultivars: Tissue-Specific Iron Speciation and Phytate and Non-Phytate Ligand Ratio
}

\author{
Paula Pongrac $1, *\left(\mathbb{0}\right.$, Iztok Arčon ${ }^{1,2}$, Hiram Castillo-Michel ${ }^{3}$ and Katarina Vogel-Mikuš ${ }^{1,4}$ \\ 1 Jožef Stefan Institute, Jamova 39, SI-1000 Ljubljana, Slovenia; iztok.arcon@ung.si (I.A.); \\ katarina.vogelmikus@bf.uni-lj.si (K.V.-M.) \\ 2 Laboratory for quantum optics, University of Nova Gorica, Vipavska 13, SI-5000 Nova Gorica, Slovenia \\ 3 European Synchrotron Radiation Facility, 38043 Grenoble, France; hiram.castillo_michel@esrf.fr \\ 4 Biotechnical Faculty, University of Ljubljana, Jamnikarjeva 101, SI-1000 Ljubljana, Slovenia \\ * Correspondence: paula.pongrac@ijs.si; Tel.: +386-51-222-963; Fax: +386-477-31-51
}

Received: 10 December 2019; Accepted: 6 January 2020; Published: 8 January 2020

\begin{abstract}
In wheat (Triticum aestivum L.), the awns-the bristle-like structures extending from lemmas-are photosynthetically active. Compared to awned cultivars, awnletted cultivars produce more grains per unit area and per spike, resulting in significant reduction in grain size, but their mineral element composition remains unstudied. Nine awned and 11 awnletted cultivars were grown simultaneously in the field. With no difference in 1000-grain weight, a larger calcium and manganese-but smaller iron ( $\mathrm{Fe}$ ) concentrations-were found in whole grain of awned than in awnletted cultivars. Micro X-ray absorption near edge structure analysis of different tissues of frozen-hydrated grain cross-sections revealed that differences in total Fe concentration were not accompanied by differences in Fe speciation (64\% of Fe existed as ferric and 36\% as ferrous species) or Fe ligands (53\% were phytate and $47 \%$ were non-phytate ligands). In contrast, there was a distinct tissue-specificity with pericarp containing the largest proportion (86\%) of ferric species and nucellar projection $(49 \%)$ the smallest. Phytate ligand was predominant in aleurone, scutellum and embryo $(72 \%, 70 \%$, and $56 \%$, respectively), while nucellar projection and pericarp contained only non-phytate ligands. Assuming Fe bioavailability depends on Fe ligands, we conclude that Fe bioavailability from wheat grain is tissue specific.
\end{abstract}

Keywords: biofortification; phytate; iron; awn; X-ray fluorescence; X-ray absorption spectrometry; phosphorus; sulphur; nicotianamine

\section{Introduction}

Mineral micronutrient sufficiency - a prerequisite for human well-being — can be ensured by diet diversification or consumption of mineral-dense produce [1]. In human diets, mineral micronutrients are predominantly acquired from plant-based sources, in particular staple grain [2,3]. However, most mineral micronutrients (manganese $(\mathrm{Mn})$, iron $(\mathrm{Fe})$, copper $(\mathrm{Cu})$ and zinc $(\mathrm{Zn}))$ in grain are tightly bound in phytate (myo-inositol hexakisphosphate), a phosphorus (P)-rich salt, which cannot be digested by mammals. This makes phytate-bound mineral elements poorly bioavailable and ineffectively exploited for normal body functions [4]. Furthermore, mineral density of the cereal grain has been for a long time regarded as of minor importance compared to the crop yield [5] resulting in prevalent micronutrient deficiencies in humans [6]. 
Efforts to increase bio-available concentrations of mineral elements in staple crops to remedy mineral micronutrient deficiencies-particularly in marginal populations-have been invested recently, and are referred to as biofortification $[7,8]$. Of the seven mineral elements often lacking in our diets, Fe deficiency is most widespread, affecting up to $60 \%$ of the global population [7]. However, increasing bio-available Fe concentration through the agronomic and genetic approaches in crops is challenging [9] for several reasons: (i) poor Fe availability in the soils limits uptake into plant roots [10], (ii) strict metabolic control over Fe accumulation and sequestration in plants tissues (sufficiency ranging between 50 and $150 \mathrm{mg} \mathrm{Fe} \cdot \mathrm{kg}^{-1}$ dry weight in leaves of crop plants [11]), (iii) removal of Fe-rich layers during the processing of staple grain [12], and (iv) poor Fe bioavailability from phytate-rich produce such as cereal grain [13].

A large degree of variation in the accumulation of Fe in grain and seeds has been found in different crops, which is not a result from just the environmental factors. For example, in bread wheat (Triticum aestivum L.) grain, the variation in total Fe concentration, i.e., a ratio between the minimum and maximum total Fe concentration in grain, was up to 1.76 [14], in barley (Hordeum vulgare L.) the variation was up to 4.5 [15], in rice (Oryza sativa L.) up to 10.7 in flooded conditions and up to 288 in unflooded conditions [16], in pearl millet (Pennisetum glaucum (L.) R. Br.) up to 4.4 [17], in chickpea (Cicer arietinum L.) up to 3.2, and in pea (Pisum sativum L.) up to 3.5 [18]. Following predominantly classic breeding strategies, the existing natural variation in Fe density has been exploited for the development of biofortified varieties within the HarvestPlus programme [8], which demonstrated, for different crops and in different populations, that consumption of Fe-biofortified crops provides significantly more bioavailable Fe.

Despite its obvious importance for human nutrition, the filling of the staple grain with $\mathrm{Fe}$, and understanding tissue-specific partitioning of Fe and Fe ligands remains a poorly understood subject [19]. Most grain filling processes take place through phloem tissues, which deliver Fe remobilised from the leaves. The presence of awns (bristle such as structures extending from lemmas), exhibiting photosynthetic activity accompanied by transpiration activity in wheat [20], may therefore play a role in the grain filling. This connection has not been investigated so far. It is, however, well-accepted that the level of phloem-mobility of a mineral element significantly affects its concentration and location in the grain, with elements such as calcium (Ca), exhibiting poor phloem mobility, not easily reaching the filial tissues of the grain and mostly remaining in the pericarp (maternal) tissues of the grain $[12,21,22]$. Iron has intermediate phloem mobility [23,24], so relatively large concentrations (exceeding those in leaves) of Fe have been found in some filial tissues of different staple grain, particularly the aleurone and embryo with values in the range from 200 to $400 \mathrm{mg} \mathrm{Fe} \cdot \mathrm{kg}^{-1}$ and from 100 to $200 \mathrm{mg} \mathrm{Fe} \cdot \mathrm{kg}^{-1}$, respectively [12,15,25-28]. In these grain tissues, Fe was found to strongly co-localise with P $[12,28-30]$. Since approximately $80 \%$ of total $\mathrm{P}$ in the grain is in the form of phytate stored mainly in the aleurone cells [31], it has been inferred that the majority of Fe is bound to phytate in these tissues. Co-localisation analyses can, however, only predict potential ligands, not unambiguously determine the Fe binding environment, so conclusions must be drawn carefully when $P$ is being used as a proxy for phytate. Using X-ray absorption near edge structure (XANES), which enables simultaneous analysis of Fe chemical form (speciation) and the type of complexing agents, it has been shown that around $80 \%$ of $\mathrm{Fe}$ in the whole grain of different wheat cultivars is bound to phytate, $15 \%$ to $24 \%$ as $\mathrm{Fe}^{2+}$ (ferrous) and $57 \%$ to $85 \%$ as $\mathrm{Fe}^{3+}$ (ferric) species [25]. Obtaining Fe K-edge XANES spectra of sufficiently high signal-to-noise ratio is a challenging task, with Fe concentrations typically found in grains and particularly in endosperm $\left(<20 \mathrm{mg} \mathrm{Fe} \cdot \mathrm{kg}^{-1}\right.$ in wheat [12,32], barley [15], and Tartary buckwheat (Fagopyrum tataricum Gaertn.) [21]), thus such studies remain scarce. One way to circumvent these technical challenges is to combine reliable Fe distribution mapping, which identifies tissues or cell-types with the largest Fe concentrations, with micro-XANES analysis. One such study, conducted on cotyledons (containing on average $187 \mathrm{mg} \mathrm{Fe} \cdot \mathrm{kg}^{-1}$ [21]) of Tartary buckwheat grain showed that $47 \%$ of $\mathrm{Fe}$ was bound to phytate, $22 \%$, of that as $\mathrm{Fe}^{2+}$ and $25 \%$ as $\mathrm{Fe}^{3+}$, while the remaining $\mathrm{Fe}^{3+}$ was bound to citrate [33]. Furthermore, in wheat aleurone, modified aleurone (surrounding the crease) and in 
nucellar projection the micro-XANES analysis indicated that Fe was bound to phytate/citrate, phytate, and Fe-nicotianamine/Fe oxide-hydroxide, respectively [28]. However, tissue-specific Fe speciation was not resolved [28] and the XANES analysis in pericarp and embryo have not been acquired so far.

Therefore, the aim of the study was to compare mineral element composition of the awned and awnletted (those that have short or no awns) cultivars and to determine tissue-specific Fe speciation and Fe ligands in the contrasting cultivars to test the following hypotheses: (i) the presence of awns affects the mineral element composition of the wheat grain, (ii) majority of $\mathrm{Fe}$ is bound to phytate in different tissues of wheat grain, (iii) Fe speciation and Fe ligands across different wheat cultivars are stable, and (iv) Fe ligand profile depends on local Fe concentration.

\section{Results}

\subsection{Total Concentrations of Mineral Elements in Whole Wheat Grain}

A significantly larger total concentration of $\mathrm{Ca}$ and $\mathrm{Mn}$, but significantly smaller total concentration of Fe was found in whole grain of awned wheat cultivars than in awnletted cultivars (Figure 1).

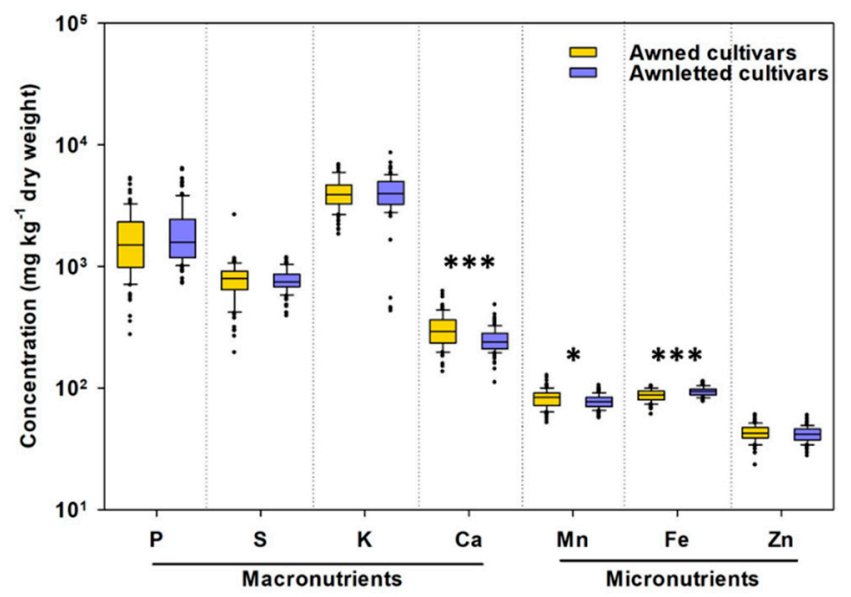

Figure 1. Variability in the total concentration of phosphorus $(\mathrm{P})$, sulphur $(\mathrm{S})$, potassium $(\mathrm{K})$, calcium $(\mathrm{Ca})$, manganese $(\mathrm{Mn})$, iron (Fe), and zinc $(\mathrm{Zn})$ in whole grain of wheat (Triticum aestivum $\mathrm{L}$.) cultivars differing in the awn type (awned cultivars have long awns and awnletted cultivars have short or no awns) grown in the same field. Shown are boxplots representing 25th and 75th percentile of the data, with the middle line representing the median, whiskers representing the 5th and 95th percentile and the black dots representing outliers ( $n=87$ and $n=100$ data points of nine awned and 11 awnletted wheat cultivars, respectively). Asterisks indicate significant differences between the awned and the awnletted cultivars (Student $t$-test; ${ }^{* * *} p<0.001$ and ${ }^{*} p<0.05$ ).

The total concentration of Fe in the awned wheat cultivars ranged from 50.8 to $94 \mathrm{mg} \cdot \mathrm{kg}^{-1}$ dry weight (1.85-fold variability) and in the awnletted wheat genotypes from 67.3 to $103 \mathrm{mg} \cdot \mathrm{kg}^{-1} \mathrm{dry}$ weight (1.53-fold variability). Considering all wheat cultivars studied, total Fe concentration in whole grain varied 2.03-fold.

There was no difference in 1000-grain weight (Table S1) and in concentrations of $\mathrm{P}$, sulphur (S), potassium $(\mathrm{K})$ and $\mathrm{Zn}$ in the whole grain between the awned and the awnletted wheat cultivar group (Figure 1), nor was there any apparent separation of awned and awnletted cultivars when the whole elemental profile was considered (Figure S1). The hierarchical clustering indicated that Fe and Zn were grouped apart from the rest of the mineral elements, among which $\mathrm{P}, \mathrm{K}$, and $\mathrm{S}$ grouped apart from $\mathrm{Ca}$ and Mn (Figure S1). A significant positive correlation was observed between grain concentrations of $P$ and those of $\mathrm{K}, \mathrm{S}$, and $\mathrm{Fe}$, but no significant correlation between grain concentrations of $\mathrm{P}$ and $\mathrm{Ca}, \mathrm{Mn}$, and $\mathrm{Zn}$ (Figure S2a). Positive correlation was found between grain concentration of Fe and $\mathrm{Mn}$, and of Fe and Zn (Figure S2b). 
Four wheat cultivars with contrasting Fe concentrations were selected for further in-depth analyses: Two awned cultivars (cv. Vulkan and cv. Soissons) of low-Fe accumulation (the average total concentrations in the grain was 73.4 and $77.0 \mathrm{mg} F e \cdot \mathrm{kg}^{-1}$ dry weight, respectively), and two awnletted cultivars (cv. Katarina and cv. Super Zitarka) of high-Fe accumulation (the average total Fe concentrations in the grain was 83.7 and $91.3 \mathrm{mg} \mathrm{Fe} \cdot \mathrm{kg}^{-1}$ dry weight, respectively; Figure 2). In agreement with observations for all wheat cultivars studied, there was a positive correlation between grain $\mathrm{P}$ concentrations and grain S, K, and Fe concentration (Figure S3a) and between grain Fe and grain $\mathrm{Zn}$ (but not Mn) concentrations (Figure S3b) in these four wheat cultivars.

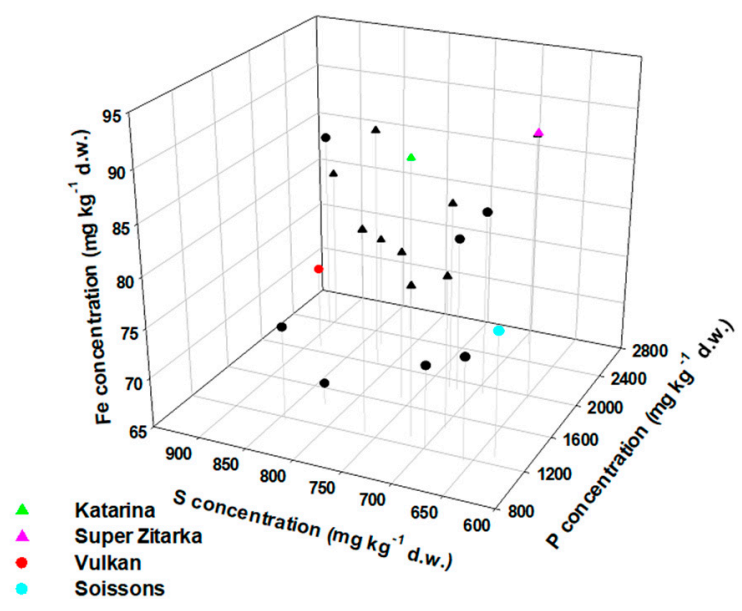

Figure 2. Total iron (Fe), sulphur (S) and phosphorus $(\mathrm{P})$ concentrations in the grain of wheat (Triticum aestivum L.) cultivars differing in the awn type (awned cultivars have long awns and awnletted cultivars have short or no awns) grown in the same field. Circles represent awned cultivars and triangles represent awnletted cultivars. The four cultivars (Katarina, Super Zitarka, Vulkan and Soissons) selected for further in-depth analyses are highlighted in colour. Shown are averages $(n=6-12)$. d.w.- dry weight.

\subsection{Tissue-Specific Iron, Phosphorus and Sulphur Concentrations, Iron Speciation and Iron Ligands}

Iron species and Fe ligands were studied in two different regions of interests (Figure 3) of the frozen-hydrated grain cross-sections of the four wheat cultivars. The first region of interest comprised nucellar projection, modified aleurone, endosperm, transfer cells, and scutellum. The second region of interest comprised aleurone, scutellum, embryo, endosperm, and pericarp.

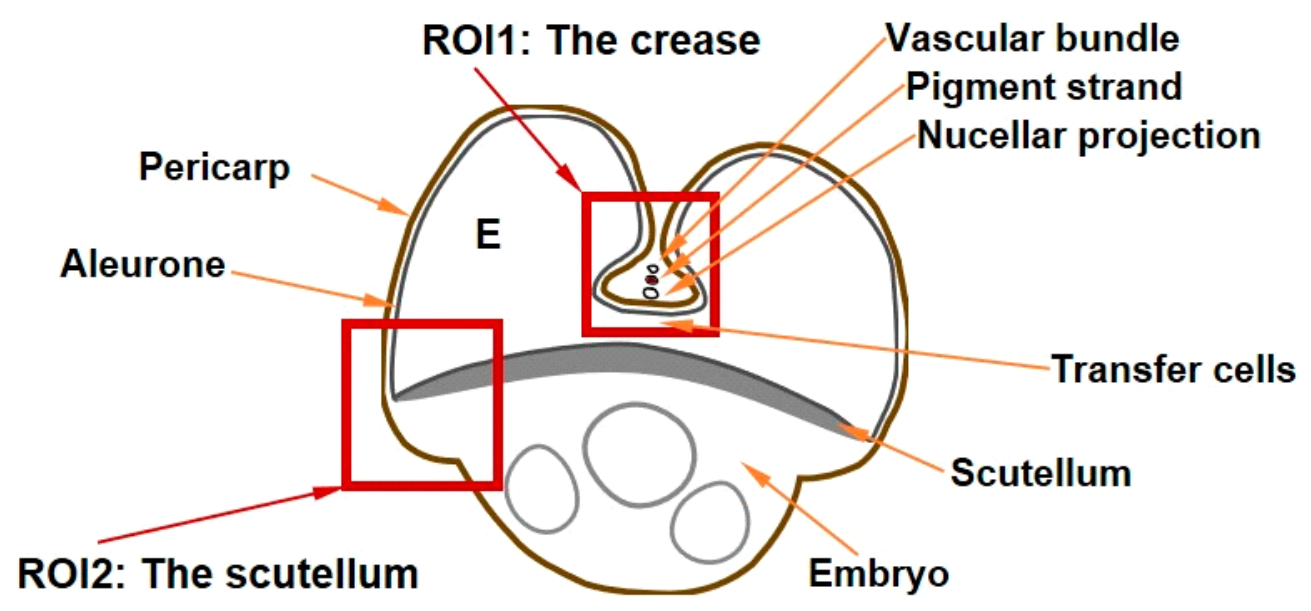

Figure 3. A representative wheat (Triticum aestivum L.) grain cross section with the two regions of interest (ROI) highlighted with red squares, namely ROI1 (the crease) and ROI2 (the scutellum). E-endosperm. 
To identify higher Fe signal pixels—selected for subsequent micro-XANES analysis-the regions of interest were first subjected to a fast (to avoid photoreduction of Fe by the focused X-ray beam) micro-XRF mapping at the ID21 beamline at ESRF to localise Fe, $\mathrm{P}$, and $\mathrm{S}$ (the quantitative maps are shown in Figures S4 and S5). By identifying Fe hotspots, the best signal-to-noise ratio in Fe K-edge micro-XANES spectra was ensured. In endosperm, the concentrations of Fe were too small (on average $3.5 \mathrm{mg} \cdot \mathrm{kg}^{-1}$ fresh weight in imbibed grains of awned cultivars and $11.4 \mathrm{mg} \cdot \mathrm{kg}^{-1}$ fresh weight in imbibed grains of awnletted cultivars) to yield micro-XANES spectra of sufficient quality. Similarly, larger Fe concentrations were found in aleurone and in pericarp of the awnletted cultivars (82.3 and $24.6 \mathrm{mg} \cdot \mathrm{kg}^{-1} \mathrm{Fe}$ fresh weight, respectively) than in aleurone of the awned cultivars (49.2 and $12.2 \mathrm{mg} \cdot \mathrm{kg}^{-1} \mathrm{Fe}$ fresh weight, respectively). By contrast, in embryo and nucellar projection the average Fe concentration of awned cultivars ( 33.8 and $160 \mathrm{mg} \cdot \mathrm{kg}^{-1} \mathrm{Fe}$ fresh weight, respectively) was larger than in awnletted cultivars (12.5 and $92 \mathrm{mg} \cdot \mathrm{kg}^{-1} \mathrm{Fe}$ fresh weight, respectively). In scutellum, both cultivars contained similar Fe concentration $\left(60.5 \mathrm{mg} \cdot \mathrm{kg}^{-1} \mathrm{Fe}\right.$ fresh weight in awned cultivars and $64 \mathrm{mg} \cdot \mathrm{kg}^{-1} \mathrm{Fe}$ fresh weight in awnletted cultivars).

The micro-XANES spectra from selected Fe hotspots ( 2 to 4 per section as indicated on the Fe, $\mathrm{P}$ and $\mathrm{S}$ co-localisation maps in Figures 4 and 5) were compared to the spectra of the Fe reference compounds and complexes (Figure S6; reported previously [25,33]).

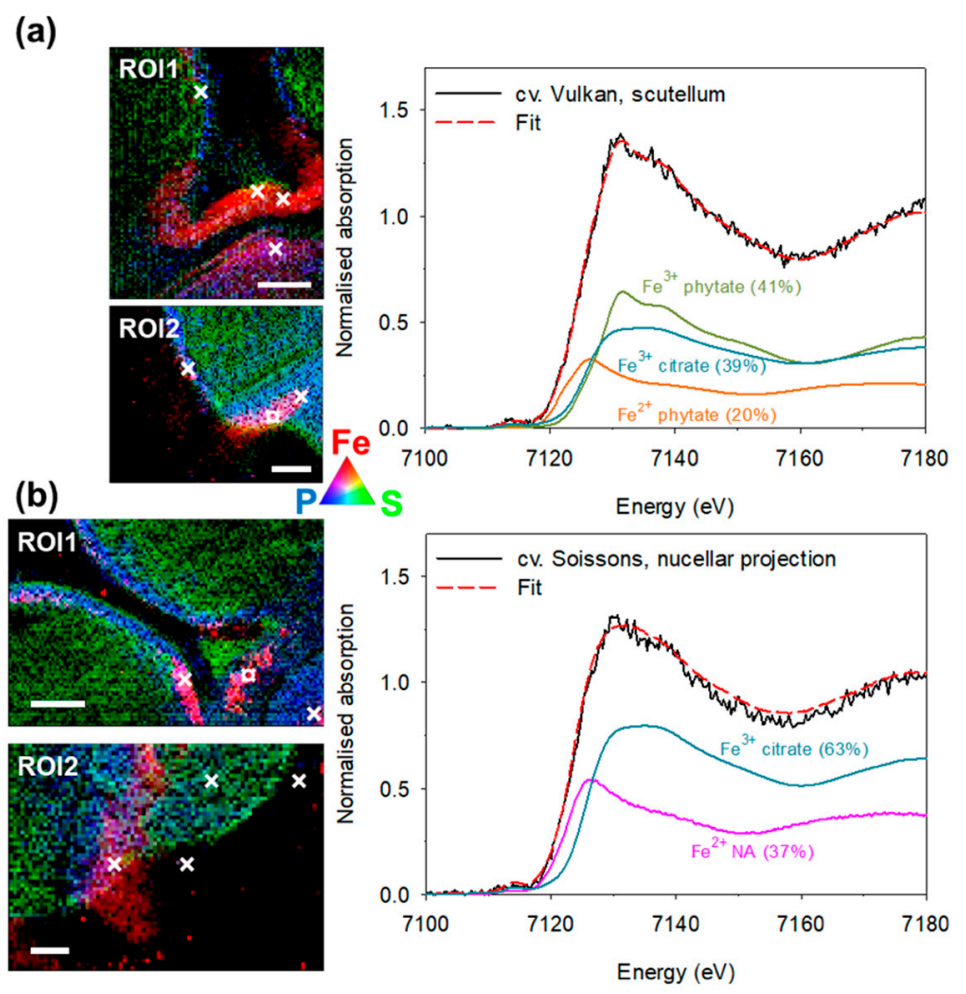

Figure 4. Co-localisation images of iron $(\mathrm{Fe})$ in red, sulphur $(\mathrm{S})$ in green and phosphorus $(\mathrm{P})$ in blue in the two regions of interest (ROI): the crease (ROI1) and the scutellum (ROI2) in the frozen-hydrated grain of wheat (Triticum aestivum L.) cultivar Vulkan (a) and Soissons (b), the awned wheat cultivars. $\times$ indicates pixels where Fe K-edge micro-XANES spectra were recorded and a indicates where the selected Fe K-edge micro-XANES spectra (solid line) was recorded and is displayed on the right-hand side. The best linear combination fit (red dashed line) was obtained by the spectra of the reference Fe compounds. The relative amount of each component is given in parentheses. eV-electron volts; NA-nicotianamine. Scale bars $=200 \mu \mathrm{m}$. Quantitative distribution maps of Fe, P and S can be found in Figure S4. 
(a)

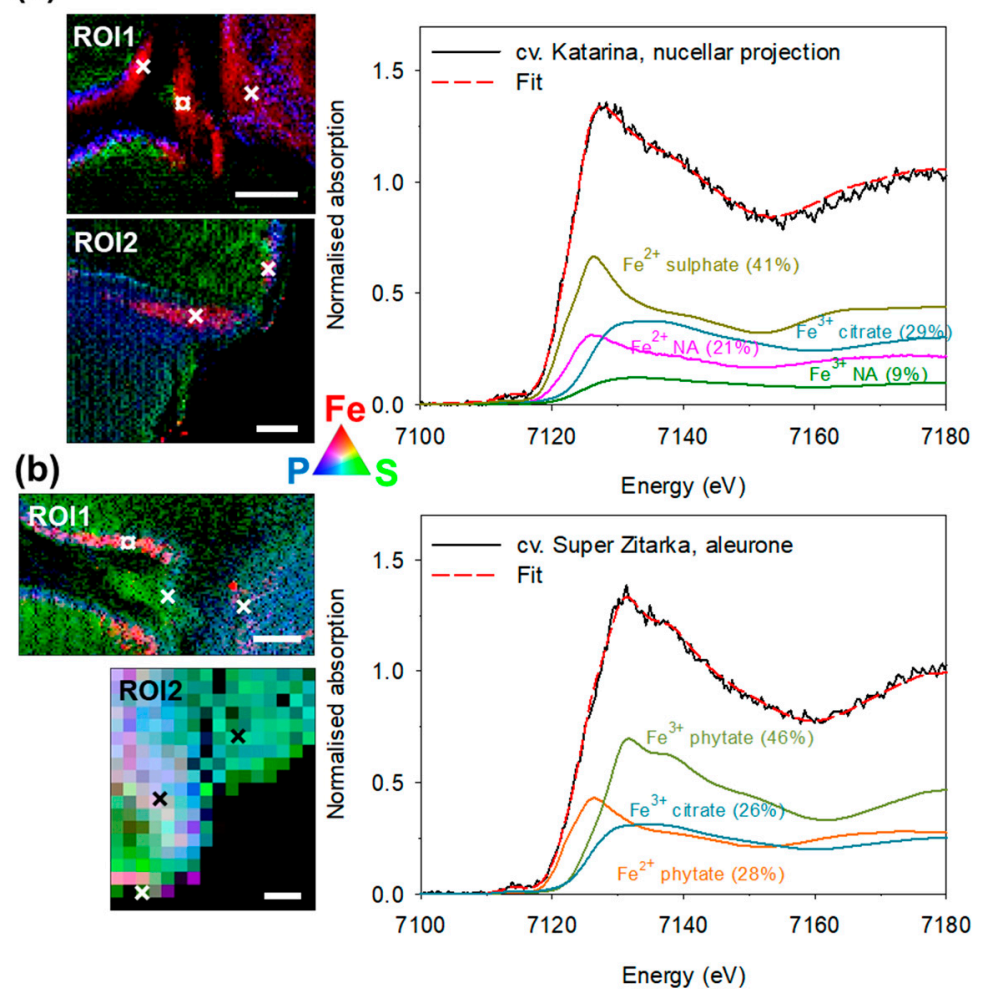

Figure 5. Co-localisation images of iron $(\mathrm{Fe})$ in red, sulphur $(\mathrm{S})$ in green and phosphorus $(\mathrm{P})$ in blue in the two regions of interest (ROI): the crease (ROI1) and the scutellum (ROI2) in the frozen-hydrated grain of wheat (Triticum aestivum L.) cultivar Katarina (a) and Super Zitarka (b), the awnletted wheat cultivars. $\times$ indicates pixels where Fe K-edge micro-XANES spectra were recorded and $a$ indicates where the selected Fe K-edge micro-XANES spectra (solid line) was recorded and is displayed on the right-hand side. The best linear combination fit (red dashed line) was obtained by the spectra of the reference Fe compounds. The relative amount of each component is given in parentheses. $\mathrm{eV}$-electron volts; NA-nicotianamine. Scale bars $=200 \mu \mathrm{m}$. Quantitative distribution maps of $\mathrm{Fe}, \mathrm{P}$ and S can be found in Figure S5.

The Fe K-edge micro-XANES spectra could be described as linear combinations of the Fe K-edge XANES spectra of the following $\mathrm{Fe}$ complexes: $\mathrm{Fe}^{2+}$ phytate, $\mathrm{Fe}^{2+}$ sulphate, $\mathrm{Fe}^{2+}$ nicotianamine, $\mathrm{Fe}^{3+}$ phytate, $\mathrm{Fe}^{3+}$ nicotianamine, $\mathrm{Fe}^{3+}$ citrate, and $\alpha-\mathrm{Fe}^{3+} \mathrm{OOH}$ (Fe oxide-hydroxide; goethite). Relative amount of each Fe complex in the combination (Table S2) was obtained from the best fit with a $\pm 1 \%$ error for the $\mathrm{Fe}^{2+} / \mathrm{Fe}^{3+}$ complex ratio and $\mathrm{a} \pm 5 \%$ error for the $\mathrm{Fe}^{3+}$ phytate $/ \mathrm{Fe}^{3+}$ non-phytate ratio.

On average, the four cultivars did not differ in the Fe species and Fe ligand composition (Figure 6a,c). Ferric species was predominant in all four cultivars, with $64 \%$ of the total Fe found in this form (Figure $6 a$ ), which was a cumulation of $26 \%$ being phytate ligand and $38 \%$ non-phytate ligands. The remaining Fe was present as ferrous species (36\%) in all four cultivars, which was a cumulation of $27 \%$ bound to phytate and $9 \%$ to non-phytate ligands. In total, $53 \%$ of Fe was found bound to phytate and the remaining $47 \%$ to non-phytate ligands (Figure $6 \mathrm{~b}$ and Table S2). 

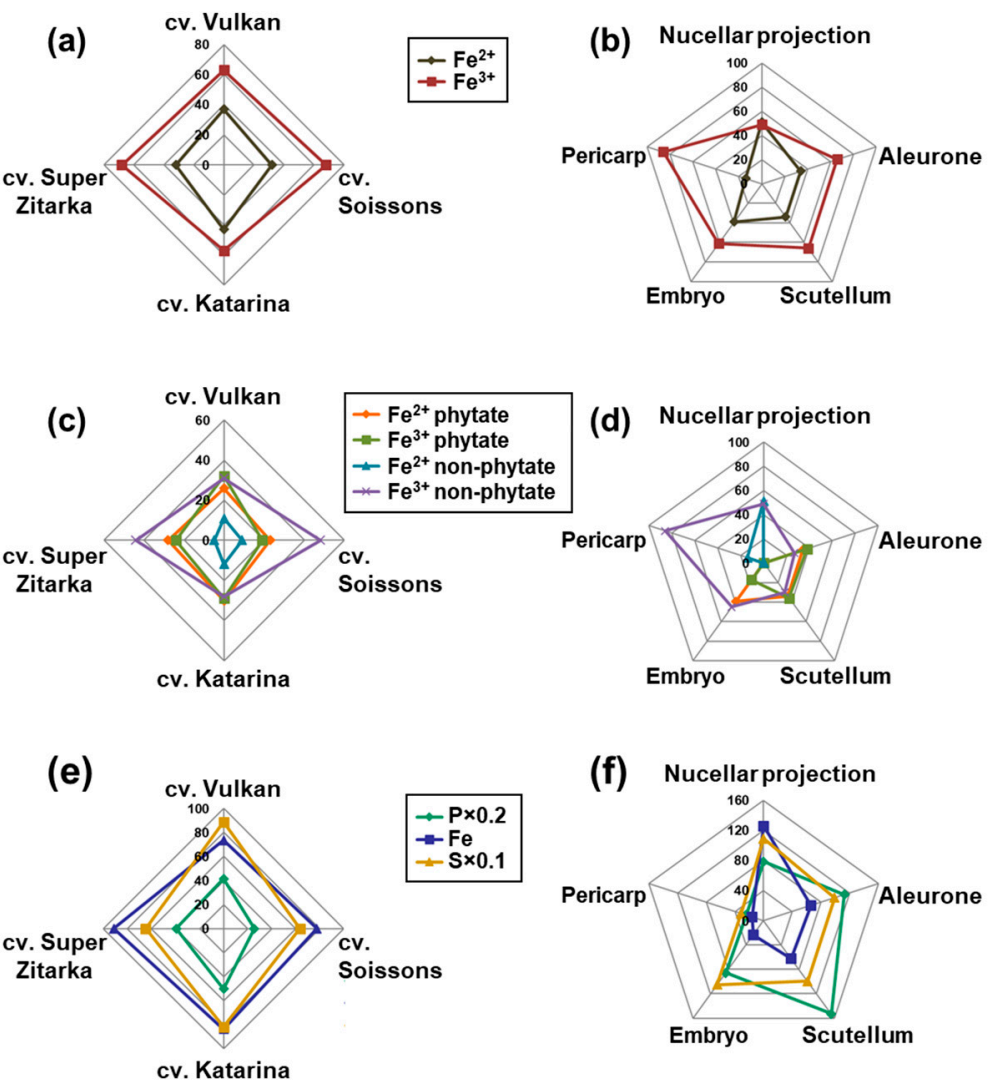

Figure 6. Average relative amounts (\%) of iron (Fe) species, Fe ligands and Fe, phosphorus (P) and sulphur (S) concentration in the grain of wheat (Triticum aestivum L.) cultivars Vulkan and Soissons (awned wheat cultivars) and Katarina and Super Zitarka (awnletted wheat cultivars) (a,c,e) and in grain tissues $(\mathbf{b}, \mathbf{d}, \mathbf{f})$. Phosphorus, Fe and $\mathrm{S}$ concentrations are in $\mathrm{mg} \cdot \mathrm{kg}^{-1}$ dry weight (e) or fresh weight (f). In (b,d,f) results indicate average across all four cultivars.

A significant tissue-specificity for Fe speciation and Fe ligand composition was observed (Figure $6 \mathrm{~b}, \mathrm{~d}$ ). In all tissues studied, the majority of Fe species were ferric-except in nucellar projection, with equal contribution of ferric and ferrous species (Figure 6b). In the order of decreasing content of ferric species, the list of tissues is: pericarp $<$ aleurone $=$ scutellum $<$ embryo $<$ nucellar projection (Figure $6 \mathrm{~b}$ ). By the proportion of phytate ligands, the tissues were ordered as: aleurone $<$ scutellum $<<$ embryo $<<$ nucellar projection = pericarp, with the latter two tissues having no phytate ligands, but only non-phytate ligands (Figure $6 \mathrm{~d}$ and Table S2). Of non-phytate ligands in nucellar projection $\mathrm{Fe}^{3+}$ citrate was most prominent (34\%), followed by $\mathrm{Fe}^{2+}$ nicotianamine (29\%), $\mathrm{Fe}^{2+}$ sulphate $(22 \%)$ and $\mathrm{Fe}^{3+}$ nicotianamine. By contrast, the pericarp contained mostly $\mathrm{Fe}^{3+}$ oxide-hydroxide $(52 \%)$, followed by $\mathrm{Fe}^{3+}$ nicotianamine $(23 \%), \mathrm{Fe}^{2+}$ sulphate $(14 \%)$ and $\mathrm{Fe}^{3+}$ citrate $(12 \%)$. Of non-phytate ligands in other tissues, only $\mathrm{Fe}^{3+}$ citrate was found, with the largest proportions in embryo $(45 \%)$, followed by scutellum $(30 \%)$ and aleurone $(27 \%)$. No clear correlation between the total and local Fe, $\mathrm{P}$ and $\mathrm{S}$ concentration and the Fe ligand profile in tissues could be discerned (Figure 6e,f). The nucellar projection contained the largest concentration of $\mathrm{Fe}$, while pericarp contained the smallest concentration of $\mathrm{Fe}, \mathrm{P}$ and $\mathrm{S}$ (Figure 6f).

\section{Discussion}

The frequent lack in intake of essential mineral elements in human diets can be significantly improved by shaping agronomic practice and/or designing staple crops to generate mineral-dense produce [7]. Agronomic approaches have been efficient when (i) the soil contains insufficient amounts 
of certain element(s), which can be added to the agricultural system as fertilizers or (ii) when changes to phytoavailability of elements in the rhizosphere are required and $\mathrm{pH}$-related intervention can offer solutions. On the other hand, variability in the elemental composition of the edible produce can be exploited to (i) introduce cultivars with superior mineral-use efficiency, provided there is no penalty to agronomically important traits or (ii) to identify candidate genes for future genetic optimisation [9]. After these interventions are implemented and a produce with the largest possible inherent concentration is available, the Fe status of the individual and other food components (e.g., dietary fibre, organic acids) will still play crucial roles in the availability of a certain element, with Fe being particularly problematic [34], further complicating the efforts to ensure optimal nutrition in humans.

\subsection{Awned Cultivars Accumulate More Ca and Mn But Less Fe in Grain than Awnletted Wheat Cultivars}

We investigated the diversity in grain mineral element accumulation in 20 wheat cultivars and found that there is a link between the awn length and the $\mathrm{Ca}, \mathrm{Mn}$ and Fe concentrations (Figure 1). In wheat, awns have been shown to have transpiration and photosynthetic activity [20], thus their presence could contribute to the translocation of elements taken up by roots on the one side and/or to the phloem-driven (re)allocation of assimilates on the other side, thereby affecting mineral element density in the grain. This connection has, however, not been investigated so far. Awnletted wheats have been shown to produce significantly more grains per unit area and per spike, resulting in a significant reductions in grain size and an increased frequency of small, shrivelled grains [35]. Our observations did not fully support this report, since there was no significant difference in 1000-grain weight between the awned and awnletted cultivars, both for the established agronomic values and for those from our experiment (Table S1). The observed differences in elemental concentrations are conceivably not a consequence of dilution by grain weight, but rather arise from genetic differences in uptake, allocation and/or mobilisation or $\mathrm{Ca}, \mathrm{Mn}$ and Fe in these cultivars. It may however be, that by accumulating larger Fe concentration in the embryo and particularly in the nucellar projection in awned cultivars compared to awnletted cultivars as observed in our study, less Fe is being translocated to other grain tissues, resulting in larger total Fe concentration in the whole grain.

On average, total Fe concentrations in grain from our experiment showed 2.03-fold variability (Figure 2), which is in a similar range as the value 1.76 reported for 150 bread wheat cultivars [14]. The whole grain Fe concentrations in all studied cultivars exceed the reported maximum value $\left(50.8 \mathrm{mg} \mathrm{Fe} \cdot \mathrm{kg}^{-1}\right)$ for the bread wheat cultivars [14], but were within the range of observations in spelt (Triticum spelta L.) grain, for which up to $99 \mathrm{mg} \mathrm{Fe} \cdot \mathrm{kg}^{-1}$ was found, but with significant variation due to the year and the location [36]. Iron concentration in barley grain exceeding $100 \mathrm{mg} \cdot \mathrm{kg}^{-1}$ has also been reported [37].

The positive correlation between P and Fe concentrations was observed (Figures S2 and S3) in agreement with findings in bread wheat [14] and in spelt [36], suggesting that the increased Fe concentration may be accompanied by a decreased bioavailability (i.e., due to phytate), presenting a further challenge for biofortification. However, the positive relationship has not been observed in all instances $[38,39]$ and a strong genotype, environment and/or genotype $\times$ environment interaction has been shown to affect the relationship $[40,41]$. The positive correlation between grain Fe and $\mathrm{Zn}$ observed also in our experiment (Figures S2 and S3), seems to be quite stable as it has been consistently reported, over different seasons and locations, for example in wheat [14,38], durum wheat [39], spelt [36], and barley $[15,37]$. It could be attributed to the limited specificity of transporters and metal ligands for either $\mathrm{Zn}$ or Fe [42], suggesting that the increased density could be achieved simultaneously for a larger number of trace elements. Still, the issues with the bioavailability of these trace elements will have to be addressed before any such observations are implemented into breeding strategies. 


\subsection{Iron Speciation and Iron Ligands in Wheat Grain Are Stable across Cultivars Differing in Total Iron Concentration}

To complement the current knowledge on Fe speciation and Fe ligands in whole wheat grain [25] and some of its tissues [28] we studied these traits in five grain tissues of four wheat cultivars. Initial $X$-ray fluorescence mapping in frozen hydrated cross-sections of the grain revealed Fe hotspots and provided information on $\mathrm{P}$ and $\mathrm{S}$ distribution as well. Based on the co-localisation of $\mathrm{Fe}, \mathrm{P}$, and $\mathrm{S}$ (Figures 4 and 5), selected regions of interest (Figure 3) were easily distinguished and high-Fe pixels were investigated by micro-XANES. There was no apparent difference in the Fe speciation or Fe ligands in the grain of awned and awnletted cultivars, regardless of the differences in the Fe concentrations (Figure $6 \mathrm{a}, \mathrm{c}$ ) indicating that the total Fe concentration in the grain does not influence Fe species or Fe ligands. Similar results were found by Singh et al. [25], who included in the analysis a wild relative of common wheat, Aegilops kotschyi Boiss., which contains up to three times larger Fe concentrations than grain of wheat landraces. The relative amounts of ferrous (36\%) species in wheat grain-up to one third of total Fe as assessed by micro-XANES in our experiment (Figures 4-6) -was somewhat larger than in previous findings in whole wheat with values between $14 \%$ and $24 \%$ [25]. Furthermore, on average $53 \%$ of Fe was bound to phytate. The proportion of non-phytate ligands is in agreement with another study [28] on wheat and Tartary buckwheat grain, where $22 \%$ of total Fe was bound to non-phytate ligands [33]. Perplexingly, no direct association of the Fe ligand profile could be found with Fe bioavailability (assessed using Caco-2 cell system) in Tartary buckwheat sprouts containing a much larger proportion (55\%) of $\mathrm{Fe}^{3+}$ citrate [33]. In legume seeds, which store large amounts of Fe in ferritin, progressive accumulation of phytate with seed maturity limits Fe bioavailability, as demonstrated by comparing immature and mature pea (Pisum sativum L.) seeds [43]. Apparently, more studies are required to reach consensus on the connection between Fe ligands and Fe bioavailability from different plant-based sources.

\subsection{Distinct Tissue Specificity in Iron Speciation, Iron Ligands and Iron Concentration in Wheat Grain}

At the tissue level a large variability in the Fe speciation and Fe ligands was found (Figure 6) in line with a previous report [28], suggesting differences in bioavailability of Fe from different grain tissues. All tissues contained $>60 \%$ of ferric species in line with analyses in whole grain [25]. The only exception was nucellar projection, where equal amounts of $\mathrm{Fe}^{3+}$ and $\mathrm{Fe}^{2+}$ were found (Figure 6b). Regarding the Fe ligands, the presence of non-phytate ligands in the pericarp and nucellar projection was particularly striking (Figure 6d). The pericarp is a maternal tissue and is typically accessed by xylem, which may be a reason for the Fe-citrate pool. There is some evidence that Fe from the Tartary buckwheat pericarp [33] and from the wheat bran [44] is relatively bioavailable. While Tartary buckwheat pericarp is not edible, the inclusion of wheat bran in the meal would, despite markedly increased phytate concentration, outweigh the negative effect of phytate-induced losses in bioavailability.

The major part of cereal grain loading with micro and macronutrients is presumed to take place through vasculature, which in mature grain is shrunk and borders the pigment strand, which in turn borders the nucellar projection (Figure 3). During grain maturity the tissues within the crease undergo a series of transformations, and nutrients passing into the endosperm must cross the pigment strand, the nucellar projection, and the endosperm transfer cells [45]. The nucellar projection is a part of the nucellar tissue that faces the vascular tissue, has a morphology characteristic of transfer cells [46] and contains large concentration of $\mathrm{Fe}$, while the pigment strand was rich in $\mathrm{Mn}$, making these two tissues clearly distinguishable $[12,25,32]$. As already follows from the apparent lack of co-localisation of Fe and $\mathrm{P}$ in the nucellar projection (Figures 4 and 5; [12,25]) only non-phytate ligands were found there. Our analysis also confirms the presence of nicotianamine in the nucellar projection reported previously in [28]. For the first time, ferric and ferrous nicotianamine compounds are demonstrated to exist in a grain tissue (together $45 \%$ of Fe ligands). In addition, some Fe was bound to sulphate (22\%), in agreement with previous reports [28] and predicted from $S$ localisation in this tissue (Figures 4-6, Figures S4 and S5) and exclusion of P [25]. 
In embryo, scutellum and aleurone, the only non-phytate ligand found was citrate, which is in agreement with results for cotyledons in Tartary buckwheat grain [33]. Most of the Fe present in the liquid endosperm in pea was found as a mixture of $\mathrm{Fe}^{3+}$ citrate and malate [47]. The mixture has been shown to undergo an ascorbate-driven reduction [47] which makes Fe more mobile within the developing seedling. Ferric citrate-malate complexes have been demonstrated as the main form of $\mathrm{Fe}$ circulating in pea (Pisum sativum L.) plants [19]. In pea, the mother plant transports $\mathrm{Fe}^{3+}$ malate/citrate complexes via the seed coat to the embryo, which in turn secretes ascorbate to reduce $\mathrm{Fe}^{3+}$ to $\mathrm{Fe}^{2+}$ for uptake during germination [47]. These observations suggest active participation of all grain tissues and not only crease tissues in Fe loading of the grain and seed.

\section{Conclusions}

Because awns presumably have photosynthetic activity, awned and awnletted wheat cultivars were compared for their 1000-grain weight, mineral composition and Fe speciation and Fe local chemical environment. While there was no difference in 1000-grain weight, a larger Ca and Mn, but smaller Fe concentrations, were found in whole grain of awned than in awnletted cultivars. Genetic and/ or metabolic reasons behind the observed differences in mineral composition will need to be studied in future experiments. The evaluation of Fe speciation and Fe ligands revealed that differences in total Fe concentration were not accompanied by differences in Fe speciation (on average $64 \%$ of Fe existed as ferric and $36 \%$ as ferrous species) or Fe ligands (on average $53 \%$ were phytate and $47 \%$ were non-phytate ligands) in the two awned and two awnletted cultivars studied using micro-XANES. Contrastingly, there was a distinct tissue-specificity with pericarp containing the largest proportion $(86 \%)$ of ferric species and nucellar projection $(49 \%)$ the smallest. Iron was predominantly bound to phytate in aleurone, scutellum and embryo $(72 \%, 70 \%$, and $56 \%$, respectively), while in nucellar projection and pericarp Fe was bound only to non-phytate ligands. Assuming Fe bioavailability depends on Fe ligands, we conclude that Fe bioavailability from wheat grain is tissue specific.

\section{Materials and Methods}

\subsection{Plant Material and Total Element Concentration in Grain}

The grain of 20 different wheat (Triticum aestivum L.) cultivars were obtained from the Agricultural Institute of Slovenia, with their agronomic characteristics reported in Table S1. Among these wheat cultivars, nine were awned (cv. Euclide, cv. Lukullus, cv. Vulkan, cv. Isengrain, cv. Renan, cv. Soissons, cv. Ingenio, cv. Bologna, and cv. Element) and 11 were awnletted (cv. BC Nina, cv. BC Renata, cv. Rosario, cv. Felix, cv. Renata, cv. Katarina, cv. BC Zdenka, cv. Anđelka, cv. Gracia, cv. Bastide, and cv. Super Zitarka). The plants were grown in the field of the Infrastructure centre Jablje (central Slovenia: $46^{\circ} 8^{\prime} 59^{\prime \prime} \mathrm{N}, 14^{\circ} 33^{\prime} 31^{\prime \prime} \mathrm{E}, 307 \mathrm{~m}$ above sea level) in 2014/2015 on pseudogley-gley soil type, which has a silty clay texture. The previous crop on the field site was grain maize (Zea mays L.). The field was fertilised with $205 \mathrm{~kg} \cdot \mathrm{ha}^{-1} \mathrm{~N}$ (in 5 rations), $90 \mathrm{~kg} \cdot \mathrm{ha}^{-1} \mathrm{P}_{2} \mathrm{O}_{5}$ and $120 \mathrm{~kg} \cdot \mathrm{ha}^{-1} \mathrm{~K}_{2} \mathrm{O} ; 400-750$ germinative seeds $\mathrm{m}^{-2}$ were sowed respecting interrow spacing of $12.5 \mathrm{~cm}$. Trial layout was a randomized block design with four repetitions, with each plot having $7.5 \mathrm{~m}^{2}$. At maturity, the plants were harvested, the 1000-grain weight was determined (g), the grain was homogenised and milled or stored for the localisation analyses. The ground material was pressed into pellets (6-12 for each cultivar) using a pellet die and hydraulic press. Total concentrations of $\mathrm{P}, \mathrm{S}, \mathrm{K}, \mathrm{Ca}, \mathrm{Mn}, \mathrm{Fe}$, and $\mathrm{Zn}$ were measured in whole grain samples and in standard reference material NIST SRM 1573a (tomato leaves) for quality assurance using X-ray fluorescence, as described previously [48]. Based on the total Fe concentration in the whole grain of the 20 wheat cultivars, four contrasting cultivars were selected. Cultivars Katarina and Super Zitarka, the two awnletted wheat cultivars, had a larger total Fe concentration than the two awned cultivars Vulkan and Soissons. 


\subsection{Sample Preparation and Micro-XRF Mapping and Micro-XANES Analysis}

The grain of the four wheat cultivars was soaked in MiliQ water for $2 \mathrm{~h}$ at $4{ }^{\circ} \mathrm{C}$. Whole grain was hand-cut transversely at the embryo location under a stereomicroscope into approximately $200 \mu \mathrm{m}$ thick sections using new stainless-steel platinum-coated razor blades and frozen immediately in liquid isopentane (Sigma-Aldrich, St. Louis, MO, USA) cooled by liquid nitrogen [49]. Frozen-hydrated sections were sandwiched between two Ultralene ${ }^{\circledR}$ foils (each $4 \mu \mathrm{m}$ thick), deposited on custom made $\mathrm{Cu}$ holders and analysed at the ID21 beamline (ESRF, Grenoble, France) as described previously [33]. In short, measurements of Fe K-edge micro-XANES (recorded in the energy region from 7040 to $7250 \mathrm{eV})$ were performed on high Fe pixels $(n=2-9)$ identified by fast mapping of grain sections using synchrotron radiation micro-X-ray fluorescence (micro-XRF) at the same beamline. This approach enabled the best quality micro-XANES spectra of the two regions of interest in the wheat grain: the crease and the scutellum. Specific attention was paid to avoid radiation damage and photoreduction of $\mathrm{Fe}^{3+}[50]$, as described in detail in [25,33].

The qualitative distribution maps of Fe, $\mathrm{P}$, and $\mathrm{S}$ were quantitatively analysed, as described previously $[51,52]$ and the quantitative distribution maps and co-localisation maps were generated with PyMCA software [53]. The Fe K-edge micro-XANES spectra were analysed with the IFEFFIT program package Athena [54], where linear combination fitting was performed using the following reference $\mathrm{Fe}^{2+}$ and $\mathrm{Fe}^{3+}$ complexes: $\mathrm{Fe}^{2+}$ phytate, $\mathrm{Fe}^{2+}$ nicotianamine, $\mathrm{Fe}^{2+}$ sulphate, $\mathrm{Fe}^{3+}$ phytate, $\mathrm{Fe}^{3+}$ nicotianamine, $\mathrm{Fe}^{3+}$ citrate and $\alpha-\mathrm{Fe}^{3+} \mathrm{OOH}$ - oxide/hydroxide (goethite). The preparation and analysis of these reference Fe complexes has been described elsewhere [25,33], except for Fe nicotianamine standards, which were synthesized by mixing water solution of nicotianamine (CAS 34441-14-0, Santa Cruz Biotechnology, Inc., USA) with $\mathrm{FeCl}_{2} \times 4 \mathrm{H}_{2} \mathrm{O}$ (Sigma-Aldrich) or $\mathrm{FeCl}_{3} \times 6 \mathrm{H}_{2} \mathrm{O}$ (Sigma-Aldrich) water solution at the molar ratio of 10:1 in water. Final $\mathrm{pH}$ was adjusted to 6.5-7.0. XANES spectra of the reference compounds $\mathrm{Fe}^{2+}$ nicotianamine and $\mathrm{Fe}^{3+}$ nicotianamine were measured at XAFS beamline of synchrotron Elettra (Trieste, Italy) in transmission detection mode, on homogeneous pellets with optical thickness of about 2 above Fe absorption K-edge. Iron species and Fe ligands for each wheat cultivar were obtained by averaging across all tissue-specific XANES results in each cultivar.

\subsection{Statistical Analysis}

Pairwise comparisons were tested by Student $t$-test at $p<0.05$ and linear regression analysis was performed in SigmaPlot version 13.0 (Systat Software, San Jose, CA). Clustering and heatmap was created using z-transformed average total concentrations in whole grain using function heatmap. 2 in gplots package within R i386 3.0.2 software.

Supplementary Materials: The following are available online at http://www.mdpi.com/2223-7747/9/1/79/s1. Figure S1: Hierarchical clustering and heatmap of grain elemental composition of all wheat cultivars studied. Figure S2: Correlations between element concentrations in whole grain for all wheat cultivars studied. Figure S3: Correlations between element concentrations in whole grain for the selected four wheat cultivars. Figure S4: Quantitative distribution maps in the grain of awned wheat cultivars. Figure S5: Quantitative distribution maps in the grain of awnletted wheat cultivars. Figure S6: Iron K-edge XANES of reference compounds used in the linear combination fitting. Table S1: Agronomic characteristics of the wheat cultivars studied. Table S2: Relative amounts of iron ligands in the grain wheat cultivars and in different grain tissues.

Author Contributions: Formal analysis, P.P., I.A. and K.V.-M.; investigation, P.P., I.A., H.C.-M. and K.V.-M.; project administration, K.V.-M.; visualization, P.P.; writing—original draft, P.P., H.C.-M. and K.V.-M. All authors have read and agreed to the published version of the manuscript.

Funding: The study was financed by the Slovenian Research Agency (ARRS) through programmes (P1-0212, P1-0112 and I0-0005), and projects (N7-077, J7-9418, J7-9398, N1-0105 and N1-0090).

Acknowledgments: The European Synchrotron Radiation Facility (ESRF), Grenoble, France, is acknowledged for the provision of synchrotron radiation facilities at beamline ID21 (experiment number LS-2225) and Elettra, Trieste, Italy, for access to the synchrotron radiation facilities at beamline XAFS (experiment number 20185165). The authors are grateful to Giuliana Aquilanti and Simone Pollastri from XAFS beamline of ELETTRA for expert advice on beamline operation and to Darinka Koron from the Agricultural Institute of Slovenia for kindly providing the grain of the wheat cultivars studied. 
Conflicts of Interest: The authors declare no conflict of interest.

\section{References}

1. Shenkin, A. Micronutrients in health and disease. Postgrad. Med. J. 2006, 82, 559-567. [CrossRef]

2. DellaPenna, D. Nutritional genomics: Manipulating plant micronutrients to improve human health. Science 1999, 285, 375-379. [CrossRef]

3. White, P.J.; George, T.S.; Gregory, P.J.; Bengough, A.G.; Hallett, P.D.; McKenzie, B.M. Matching roots to their environment. Ann. Bot. 2013, 112, 207-222. [CrossRef]

4. Clemens, S. Zn and Fe biofortification: The right chemical environment for human bioavailability. Plant Sci. 2014, 225, 52-57. [CrossRef]

5. Fan, M.-S.; Zhao, F.-J.; Fairweather-Tait, S.J.; Poulton, P.R.; Dunham, S.J.; McGrath, S.P. Evidence of decreasing mineral density in wheat grain over the last 160 years. J. Trace Elem. Med. Biol. 2008, 22, 315-324. [CrossRef]

6. Sands, D.C.; Morris, C.E.; Dratz, E.A.; Pilgeram, A.L. Elevating optimal human nutrition to a central goal of plant breeding and production of plant-based foods. Plant Sci. 2009, 177, 377-389. [CrossRef]

7. White, P.J.; Broadley, M.R. Biofortification of crops with seven mineral elements often lacking in human diets-Iron, zinc, copper, calcium, magnesium, selenium and iodine. New Phytol. 2009, 182, 49-84. [CrossRef]

8. Bouis, H.E.; Saltzman, A. Improving nutrition through biofortification: A review of evidence from HarvestPlus, 2003 through 2016. Glob. Food Secur. 2017, 12, 49-58. [CrossRef]

9. Connorton, J.M.; Balk, J. Iron biofortification of staple crops: Lessons and challenges in plant genetics. Plant Cell Physiol. 2019, 60, 1447-1456. [CrossRef]

10. Colombo, C.; Palumbo, G.; He, J.-Z.; Pinton, R.; Cesco, S. Review on iron availability in soil: Interaction of Fe minerals, plants, and microbes. J. Soils Sediments 2014, 14, 538-548. [CrossRef]

11. White, P.J.; Brown, P.H. Plant nutrition for sustainable development and global health. Ann. Bot. 2010, 105, 1073-1080. [CrossRef]

12. Pongrac, P.; Kreft, I.; Vogel-Mikuš, K.; Regvar, M.; Germ, M.; Vavpetič, P.; Grlj, N.; Jeromel, L.; Eichert, D.; Budič, B.; et al. Relevance for food sciences of quantitative spatially resolved element profile investigations in wheat (Triticum aestivum) grain. J. R. Soc. Interface 2013, 10. [CrossRef]

13. Collings, R.; Harvey, L.J.; Hooper, L.; Hurst, R.; Brown, T.J.; Ansett, J.; King, M.; Fairweather-Tait, S.J. The absorption of iron from whole diets: A systematic review. Am. J. Clin. Nutr. 2013, 98, 65-81. [CrossRef]

14. Zhao, F.J.; Su, Y.H.; Dunham, S.J.; Rakszegi, M.; Bedo, Z.; McGrath, S.P.; Shewry, P.R. Variation in mineral micronutrient concentrations in grain of wheat lines of diverse origin. J. Cereal Sci. 2009, 49, 290-295. [CrossRef]

15. Detterbeck, A.; Pongrac, P.; Rensch, S.; Reuscher, S.; Pečovnik, M.; Vavpetič, P.; Pelicon, P.; Holzheu, S.; Krämer, U.; Clemens, S. Spatially resolved analysis of variation in barley (Hordeum vulgare) grain micronutrient accumulation. New Phytol. 2016, 211, 1241-1254. [CrossRef]

16. Pinson, S.R.M.; Tarpley, L.; Yan, W.; Yeater, K.; Lahner, B.; Yakubova, E.; Huang, X.-Y.; Zhang, M.; Guerinot, M.L.; Salt, D.E. Worldwide genetic diversity for mineral element concentrations in rice grain. Crop Sci. 2015, 55, 294. [CrossRef]

17. Bashir, E.M.A.; Ali, A.M.; Ali, A.M.; Melchinger, A.E.; Parzies, H.K.; Haussmann, B.I.G. Characterization of Sudanese pearl millet germplasm for agro-morphological traits and grain nutritional values. Plant Genet. Resour. Character. Util. 2014, 12, 35-47. [CrossRef]

18. Available online: https://npgsweb.ars-grin.gov/gringlobal/descriptors.aspx? (accessed on 8 January 2020).

19. Grillet, L.; Mari, S.; Schmidt, W. Iron in seeds-Loading pathways and subcellular localization. Front. Plant Sci. 2014, 4, 1-8. [CrossRef]

20. Li, X.-F.; Bin, D.; Hong-Gang, W. Awn anatomy of common wheat (Triticum aestivum L.) and its relatives. Caryologia 2010, 63, 391-397. [CrossRef]

21. Pongrac, P.; Vogel-Mikuš, K.; Jeromel, L.; Vavpetič, P.; Pelicon, P.; Kaulich, B.; Gianoncelli, A.; Eichert, D.; Regvar, M.; Kreft, I. Spatially resolved distributions of the mineral elements in the grain of tartary buckwheat (Fagopyrum tataricum). Food Res. Int. 2013, 54, 125-131. [CrossRef]

22. Vogel-Mikuš, K.; Pelicon, P.; Vavpetič, P.; Kreft, I.; Regvar, M. Elemental analysis of edible grains by micro-PIXE: Common buckwheat case study. Nucl. Instrum. Methods Phys. Res. Sect. B Beam Interact. Mater. Atoms 2009, 267, 2884-2889. [CrossRef] 
23. Garnett, T.P.; Graham, R.D. Distribution and remobilization of iron and copper in wheat. Ann. Bot. 2005, 95, 817-826. [CrossRef] [PubMed]

24. White, P.J. Long-distance Transport in the Xylem and Phloem. In Marschner's Mineral Nutrition of Higher Plants, 3rd ed.; Marschner, P., Ed.; Academic Press: San Diego, CA, USA, 2012; Chapter 3; pp. 49-70. ISBN 978-0-12-384905-2.

25. Singh, S.P.; Vogel-Mikuš, K.; Arčon, I.; Vavpetič, P.; Jeromel, L.; Pelicon, P.; Kumar, J.; Tuli, R. Pattern of iron distribution in maternal and filial tissues in wheat grains with contrasting levels of iron. J. Exp. Bot. 2013, 64, 3249-3260. [CrossRef] [PubMed]

26. Eroglu, S.; Karaca, N.; Vogel-Mikuš, K.; Kavčič, A.; Filiz, E.; Tanyolac, B. The conservation of VIT1-dependent iron distribution in seeds. Front. Plant Sci. 2019, 10, 907. [CrossRef] [PubMed]

27. Ibeas, M.A.; Grant-Grant, S.; Coronas, M.F.; Vargas-Pérez, J.I.; Navarro, N.; Abreu, I.; Castillo-Michel, H.; Avalos-Cembrano, N.; Paez Valencia, J.; Perez, F.; et al. The diverse iron distribution in eudicotyledoneae seeds: From arabidopsis to quinoa. Front. Plant Sci. 2019, 9, 1-10. [CrossRef] [PubMed]

28. De Brier, N.; Gomand, S.V.; Donner, E.; Paterson, D.; Smolders, E.; Delcour, J.A.; Lombi, E. Element distribution and iron speciation in mature wheat grains (Triticum aestivum L.) using synchrotron X-ray fluorescence microscopy mapping and X-ray absorption near-edge structure (XANES) imaging. Plant. Cell Environ. 2016, 39, 1835-1847. [CrossRef]

29. Regvar, M.; Eichert, D.; Kaulich, B.; Gianoncelli, A.; Pongrac, P.; Vogel-Mikuš, K.; Kreft, I. New insights into globoids of protein storage vacuoles in wheat aleurone using synchrotron soft X-ray microscopy. J. Exp. Bot. 2011, 62, 3929-3939. [CrossRef]

30. Kyriacou, B.; Moore, K.L.; Paterson, D.; de Jonge, M.D.; Howard, D.L.; Stangoulis, J.; Tester, M.; Lombi, E.; Johnson, A.A.T. Localization of iron in rice grain using synchrotron $\mathrm{X}$-ray fluorescence microscopy and high resolution secondary ion mass spectrometry. J. Cereal Sci. 2014, 59, 173-180. [CrossRef]

31. O'Dell, B.L.; De Boland, A.R.; Koirtyohann, S.R. Distribution of phytate and nutritionally important elements among the morphological components of cereal grains. J. Agric. Food Chem. 1972, 20, 718-723. [CrossRef]

32. Singh, S.P.; Vogel-Mikuš, K.; Vavpetič, P.; Jeromel, L.; Pelicon, P.; Kumar, J.; Tuli, R. Spatial X-ray fluorescence micro-imaging of minerals in grain tissues of wheat and related genotypes. Planta 2014, 240, 277-289. [CrossRef]

33. Pongrac, P.; Scheers, N.; Sandberg, A.S.; Potisek, M.; Arčon, I.; Kreft, I.; Kump, P.; Vogel-Mikuš, K. The effects of hydrothermal processing and germination on Fe speciation and Fe bioaccessibility to human intestinal Caco-2 cells in Tartary buckwheat. Food Chem. 2016, 199, 782-790. [CrossRef] [PubMed]

34. Hurrell, R.; Egli, I. Iron bioavailability and dietary reference values. Am. J. Clin. Nutr. 2010, 91, 1461S-1467S. [CrossRef] [PubMed]

35. Rebetzke, G.J.; Bonnett, D.G.; Reynolds, M.P. Awns reduce grain number to increase grain size and harvestable yield in irrigated and rainfed spring wheat. J. Exp. Bot. 2016, 67, 2573-2586. [CrossRef] [PubMed]

36. Gomez-Becerra, H.F.; Erdem, H.; Yazici, A.; Tutus, Y.; Torun, B.; Ozturk, L.; Cakmak, I. Grain concentrations of protein and mineral nutrients in a large collection of spelt wheat grown under different environments. $J$. Cereal Sci. 2010, 52, 342-349. [CrossRef]

37. Detterbeck, A.; Nagel, M.; Rensch, S.; Weber, M.; Börner, A.; Persson, D.P.; Schjoerring, J.K.; Christov, V.; Clemens, $\mathrm{S}$. The search for candidate genes associated with natural variation of grain $\mathrm{Zn}$ accumulation in barley. Biochem. J. 2019, 476, 1889-1909. [CrossRef]

38. Morgounov, A.; Gómez-Becerra, H.F.; Abugalieva, A.; Dzhunusova, M.; Yessimbekova, M.; Muminjanov, H.; Zelenskiy, Y.; Ozturk, L.; Cakmak, I. Iron and zinc grain density in common wheat grown in Central Asia. Euphytica 2007, 155, 193-203. [CrossRef]

39. Ficco, D.B.M.; Riefolo, C.; Nicastro, G.; De Simone, V.; Di Gesù, A.M.; Beleggia, R.; Platani, C.; Cattivelli, L.; De Vita, P. Phytate and mineral elements concentration in a collection of Italian durum wheat cultivars. Field Crop. Res. 2009, 111, 235-242. [CrossRef]

40. Murphy, K.M.; Hoagland, L.A.; Yan, L.; Colley, M.; Jones, S.S. Genotype $\times$ environment interactions for mineral concentration in grain of organically grown spring wheat. Agron. J. 2011, 103, 1734. [CrossRef]

41. Joshi, A.K.; Crossa, J.; Arun, B.; Chand, R.; Trethowan, R.; Vargas, M.; Ortiz-Monasterio, I. Genotype $\times$ environment interaction for zinc and iron concentration of wheat grain in eastern Gangetic plains of India. Field. Crop. Res. 2010, 116, 268-277. [CrossRef] 
42. Li, S.; Zhou, X.; Huang, Y.; Zhu, L.; Zhang, S.; Zhao, Y.; Guo, J.; Chen, J.; Chen, R. Identification and characterization of the zinc-regulated transporters, iron-regulated transporter-like protein (ZIP) gene family in maize. BMC Plant Biol. 2013, 13, 114. [CrossRef]

43. Moore, K.L.; Rodríguez-Ramiro, I.; Jones, E.R.; Jones, E.J.; Rodríguez-Celma, J.; Halsey, K.; Domoney, C.; Shewry, P.R.; Fairweather-Tait, S.; Balk, J. The stage of seed development influences iron bioavailability in pea (Pisum sativum L.). Sci. Rep. 2018, 8, 1-11. [CrossRef]

44. Morris, E.R.; Ellis, R. Isolation of Monoferric Phytate from Wheat Bran and its Biological Value as an Iron Source to the Rat. J. Nutr. 1976, 106, 753-760. [CrossRef] [PubMed]

45. Thiel, J. Development of endosperm transfer cells in barley. Front. Plant Sci. 2014, 5, 1-12. [CrossRef] [PubMed]

46. Sreenivasulu, N.; Borisjuk, L.; Junker, B.H.; Mock, H.-P.; Rolletschek, H.; Seiffert, U.; Weschke, W.; Wobus, U. Barley Grain Development: Toward an Integrative View. In International Review of Cell and Molecular Biology; Jeon, K.W., Ed.; Academic Press: Amsterdam, The Netherlands, 2010; Volume 281, Chapter 2; pp. $49-89$.

47. Grillet, L.; Ouerdane, L.; Flis, P.; Hoang, M.T.T.; Isaure, M.-P.; Lobinski, R.; Curie, C.; Mari, S. Ascorbate efflux as a new strategy for iron reduction and transport in plants. J. Biol. Chem. 2014, 289, 2515-2525. [CrossRef] [PubMed]

48. Nečemer, M.; Kump, P.; Ščančar, J.; Jaćimović, R.; Simčič, J.; Pelicon, P.; Budnar, M.; Jeran, Z.; Pongrac, P.; Regvar, M.; et al. Application of X-ray fluorescence analytical techniques in phytoremediation and plant biology studies. Spectrochim. Acta Part B At. Spectrosc. 2008, 63, 1240-1247. [CrossRef]

49. Vogel-Mikuš, K.; Pongrac, P.; Pelicon, P. Micro-PIXE elemental mapping for ionome studies of crop plants. Int. J. PIXE 2014, 24, 217-233. [CrossRef]

50. Wang, P.; McKenna, B.A.; Menzies, N.W.; Li, C.; Glover, C.J.; Zhao, F.J.; Kopittke, P.M. Minimizing experimental artefacts in synchrotron-based X-ray analyses of Fe speciation in tissues of rice plants. J. Synchrotron Radiat. 2019, 26, 1272-1279. [CrossRef]

51. Koren, Š.; Arčon, I.; Kump, P.; Nečemer, M.; Vogel-Mikuš, K. Influence of $\mathrm{CdCl}_{2}$ and $\mathrm{CdSO}_{4}$ supplementation on $\mathrm{Cd}$ distribution and ligand environment in leaves of the Cd hyperaccumulator Noccaea (Thlaspi) praecox. Plant Soil 2013, 370, 125-148. [CrossRef]

52. Kump, P.; Vogel-Mikuš, K. Quantification of 2D elemental distribution maps of intermediate-thick biological sections by low energy synchrotron $\mu$-X-ray fluorescence spectrometry. J. Instrum. 2018, 13. [CrossRef]

53. Solé, V.A.; Papillon, E.; Cotte, M.; Walter, P.; Susini, J. A multiplatform code for the analysis of energy-dispersive X-ray fluorescence spectra. Spectrochim. Acta Part B At. Spectrosc. 2007, 62, 63-68. [CrossRef]

54. Ravel, B.; Newville, M.A. ATHENA, ARTEMIS, HEPHAESTUS: Data analysis for X-ray absorption spectroscopy using IFEFFIT. J. Synchrotron Radiat. 2005, 12, 537-541. [CrossRef] [PubMed] 